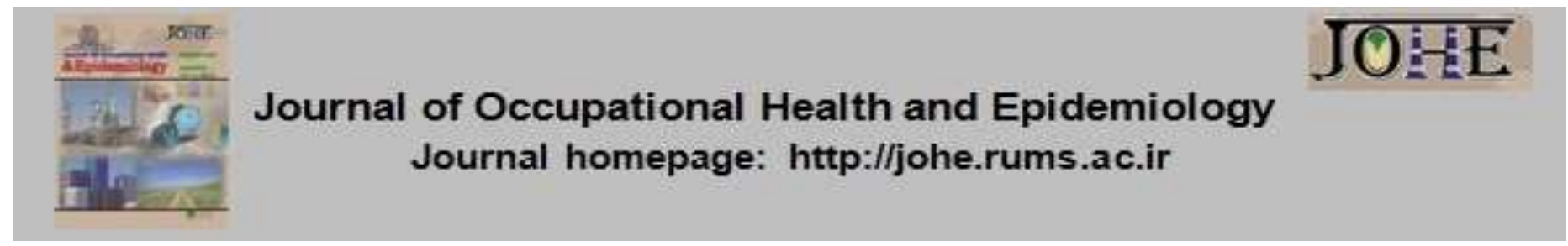

\title{
Factors influencing Occupational Ethics among Faculty Members at Farhangian University: A Mixed Method Research
}

Mirmajid Mohammadi Fomani ${ }^{1}$, Asghar Sharifi ${ }^{*}$, Al'addin Etemad Ahari²

1- PhD Student in Curriculum Planning, Faculty of Educational Sciences and Counseling, Roudehen Islamic Azad University, Roudehen, Iran.

2- Assistant Prof., of Educational Management, Faculty of Educational Sciences and Counseling, Roudehen Islamic Azad University, Roudehen, Iran.

Citation: Mohammadi Fomani M, Sharifi A, Etemad Ahari A. Factors influencing
Occupational Ethics among Faculty Members at Farhangian University: A Mixed Method
Research. JOHE 2020; 9(1):41-51.

\section{Article Info \\ * Corresponding author: \\ Asghar Sharifi, \\ E-mail: \\ drasharifi@gmail.com}

\section{Article history}

Received: Dec 2019

Accepted: Feb 2020

10.29252/johe.9.1.41

Print ISSN: 2251-8096 Online ISSN: 2252-0902

Peer review under responsibility of Journal of Occupational Health and Epidemiology

\begin{abstract}
Background: Due to the central role of ethics in the overall success of professors and teachers in developing curricula and their direct relationship with students, the present study aims to investigate the factors influencing occupational ethics in faculty members at Farhangian University.

Materials and Methods: This study uses a mixed method with a sequential explanatory design. The statistical population of the research in the qualitative section included 23 academic experts and officials of Farhangian University selected by targeted sampling. The quantitative section of the study included all faculty members of Farhangian University from all around the country, with 267 of whom selected using cluster random sampling. The research tool in the qualitative section was interviews, and researchermade questionnaire with 69 questions was used in the quantitative section. The results indicated the validity of the instrument. In addition, the Cronbach's alpha coefficient and retest results verified the reliability of the tool. Data analysis was performed through coding in the qualitative section of the research, and in the quantitative section, structural equation modelling was done using SPSS V22.0 and Lisrel V8.8.

Results: According to the results, factors influencing occupational ethics among faculty members at Farhangian University included ethical intelligence (0.124), ethical leadership (0.197), organizational commitment (0.222), organizational culture (0.099), organization climate (0.143), work engagement (0.153), interactive justice (0.153), occupational competence (0.210), and personal development (0.265).

Conclusion: The results implied that all the above-mentioned identified factors were desirable among faculty members at Farhangian University, and the proposed model had a good fit.
\end{abstract}

Keywords: Professional Ethics, Faculty, University.

\section{Introduction}

One of the major variables in the success of any organization is ethics [1]. Organizational staff prefers to work in occupational organizations because an ethical environment created by an occupation reduces unpleasant factors through teamwork and enhances job satisfaction as well as the relationship among colleagues [2].
Occupational ethics refer to the rules and standards for occupational behavior of individuals [3].Given the importance of ethics in all aspects of life, scholars in any area and at any time have found the comfort of a healthy lifestyle in a society with high levels of moral development. In this regard, some scholars believe that without ethics, scientific communities do not form, and that the scientific production process could be disrupted 
[4]. Overlooking occupational ethics by organizations and failure to adhere to ethics in dealing with organizational human resources as well as extra-organizational stakeholders could create problems for an organization and cast doubt on the legitimacy and actions of an organization [5]. In addition, researchers believe that occupational ethics create an ethical climate and improve job satisfaction in organizations [6].

Today, many countries in the industrialized world have understood that overlooking ethical issues as well as evading social responsibilities and commitments could lead to the dissolution of the firm. Therefore, many successful companies have felt the need for formulating an ethical strategy and concluded that an ethical culture should penetrate the organization [7]. Hence, they have been endeavoring to put special emphasis on doing research into occupational ethics. In the business field, occupational ethics, such as medical ethics, school ethics, engineering ethics, and the like come into play [8].

In the meantime, universities and higher education institutes, as the most sensitive organizations in the present time and perhaps in the next centuries, need to address ethics in their profession and mission more than others. Occupational ethics in general and educational ethics in particular have in recent years been of particular interest among faculty members, students, educational management scholars, and researchers. In many universities of the world, regulations titled 'occupational code of ethics' have been developed by which faculty members are obliged to abide [9]. Occupational ethics in the higher education system lead to identifying appropriate or inappropriate behaviors and guiding faculty members in performing their occupational responsibilities. Given that occupational responsibilities of professors and faculty members in universities fall into three categories, including education, research, and entrepreneurship, their occupational ethics govern these categories as well. The influencing occupational factors in educational ethics include principals, policymakers, faculties, and students, while the role of faculty members in universities is much more pronounced than other factors. In addition to their specialties in which they must be proficient, university professors should also know the school profession and be familiar with its occupational principles. Since education is the first function of universities [10], the principles of occupational ethics of education are discussed in two dimensions. Firstly, the ethical standards that must met in education, which are related to teaching and learning processes, and secondly, the principles of individual ethics based on which, individuals must commit themselves to ethics [11]. Various factors facilitate occupational ethics in university professors, including managerial factors, such as interpersonal trust between the faculty and the university management. Researchers acknowledge that trust and honesty among individuals within an organization create occupational ethics [12]. In addition, considering the individual dimension, the critical thinking ability and the ability to make the right decision are among the factors influencing occupational ethics [13]. Another influencing factor is the existence of ethical leadership. In their research, researchers point out to the relationship between ethical leadership and the creation of occupational ethics in the organization [14] and argue that accountability influences ethics in individuals [15]. In this regard, the existing research background shows that the factors of ethical commitment and ethical leadership in using information and communication technology are the two components of occupational ethics that influence the creation of a business identity [16]. Some researchers have introduced an applied model based on the theoretical and practical studies of occupational ethics in education that encompasses the dimensions of education and research [17]. Given that Farhangian University, among other universities in the country, is active as a specialized university in the field of HR education, the role of the professors at Farhangian University in developing community ethics should be taken into consideration. However, despite the brilliant historical and civilizational approach of Iranians to education as well as cultural and religious heritage, the community and especially the academic environment are currently suffering from the lack of ethical concerns in various occupations [9]. Therefore, against the background on the importance of occupational ethics in various occupations and its importance in educational organizations, including Farhangian University, it is necessary to develop coherent programs so as to improve occupational ethics among professors. In terms of Farhangian University, it could not attain its established goals without professors aware of occupational ethics. This could be realized when this university develops occupational ethics and training programs through identifying influencing factors. Accordingly, this study aims to identify factors influencing occupational ethics among the faculty members of Farhangian University. Thus, given the importance of occupational ethics in developing organizations on the one hand and their role in developing ethical behavior in the society on the other hand, this research mainly aims to identify the major factors influencing 
occupational ethics in faculty members at Farhangian University. In this study, the following objectives were pursued:

1- To determine the factors influencing occupational ethics in the faculty members of Farhangian University

2- To determine the current status of each of the identified influencing factors in occupational ethics among faculty members at Farhangian University

\section{Materials and Methods}

This study uses a mixed research approach (quantitative and qualitative) with a sequential explanatory design, and it is applied in terms of purpose. The statistical population of the qualitative section of this study consisted of academic experts and officials at Farhangian University. In the qualitative section of the study, 23 experts and officials at Farhangian University were interviewed. In the qualitative section, the sample size was determined based on the saturation principle, according to which the researcher continued interviews to the extent that new interviewees did not add new indices to the previous ones [18]. The interviewees were comprised of 4 executives, 4 top professors, 8 employees of the Education and Research Department, 4 educational experts on campus, and 3 employees from the Office for Studies and Curriculum Development at Farhangian University, who were selected by purposive sampling. The data collection tool was interviews. The statistical population of the quantitative section of the study included all faculty members at Farhangan University from all around the country. One of the methods used for estimating the sample size is the use of a formulaic approach, such as the Cochran formula [19]. The statistical population included 874 people, and the sample required for the quantitative section included 267 people, for which the Cochran formula was used at the error level of $0 / 05$. The country was divided into five regions using multistage cluster sampling, which included the north of the country (with 258 faculty members), the south of the country (with 140 faculty members), the east of the country (with 176 faculty members), the west of the country (with 199 faculty members), and the center of the country (with 101 faculty members). In addition, three campuses were selected from each region, and the researcher randomly selected the sample from each university according to the sample-tocommunity ratio. Next, he distributed the questionnaires among those faculty members who were accessible. In this research, a library research method, a semi-structured interview, and questionnaires were used for data collection. Semi-structured interviews were used in the qualitative section of this study. In the data sampling process, the researcher analyzed the data to complete the incomplete items by receiving new information from new participants. After 23 interviews, main factors and sub-factors were repeated in past interviews, and the research was saturated. During the interviews, opinions on appropriate indicators were collected to determine the factors influencing occupational ethics and the desired main factors and sub-factors were reviewed and finalized. The time of interviews was from 30 to $60 \mathrm{~min}$. To ensure the validity of the qualitative section of the research, the valuable comments of the professor's familiar with this field and those of the experts at Farhangi University, who were knowledgeable in this field, were utilized. In the meantime, the participants were asked to help analyze and interpret the data. Inter-rater reliability was also used to calculate reliability. In an interview using inter-coder reliability (ICR), one of the professors of the Educational Department familiar with coding was asked to participate in the study as a secondary coder. Next, the researcher, in cooperation with the secondary coder, coded three interviews and calculated the percentage of inter-coder reliability as the reliability index of the analysis; the reliability of the two coders was calculated at $1.75 \%$, indicating appropriate reliability.

In this study, a research-made questionnaire created by the codes of the interview for data collection was used, which was completed by surveying faculty members at Farhangian University. The items of the research questionnaires consisted of two parts, including (A) general questions, the purpose of which was to obtain general and demographic information about the respondents. This section included five questions about gender, age, education, academic rank, and work experience. The second part (B) included the Occupational Ethics ResearcherMade Questionnaires that consisted of 61 items with a five-point Likert scale developed by reviewing theoretical and practical basics as well as the results of exploratory interviews with open and axial coding of exploratory interview texts. It is worth noting that during the distribution of the questionnaires, the researcher was present and attempted to clarify the ambiguities about the content of the questionnaires verbally. In this study, face validity, content validity, and construct validity were used to calculate validity of the research. The face validity of the final questionnaire, which had no errors, was verified 
with the cooperation of the researcher, several members of the sample, supervisors, and advisors. To investigate content validity, CVR and CVI forms were used. It is worth mentioning that content validity was assessed by the experts, interviewers, supervisors, advisors, PhD students in this field, and several subjects before the distribution of the questionnaires. Based on content validity (CVR= $0 / 65$ and $C V I=0 / 84)$, no questions were omitted, but some questions were corrected. After confirming the content validity and construct validity of the research instrument, two types of convergent and divergent validity were used with the help of Lisrel software. Divergent validity was used by the Fornell and Larker test as well as the transverse load test, which was employed in a pilot study on a sample of 40 individuals of the statistical population to ensure the reliability of the questionnaires. Next, the data were analyzed using two methods (alpha coefficient). In this study, the Cronbach's alpha coefficient of the influencing factor of occupational ethics (0.88) and the retest coefficient of the influencing factor of occupational ethics (0.84) were calculated.

According to the introduction to this section, it can be said that the research method is applied in terms of purpose, and the research method is mixed (quantitative and qualitative), with a sequential explanatory design. The implementation stages of the research, in both qualitative and quantitative phases, are exhibited in the following figure:

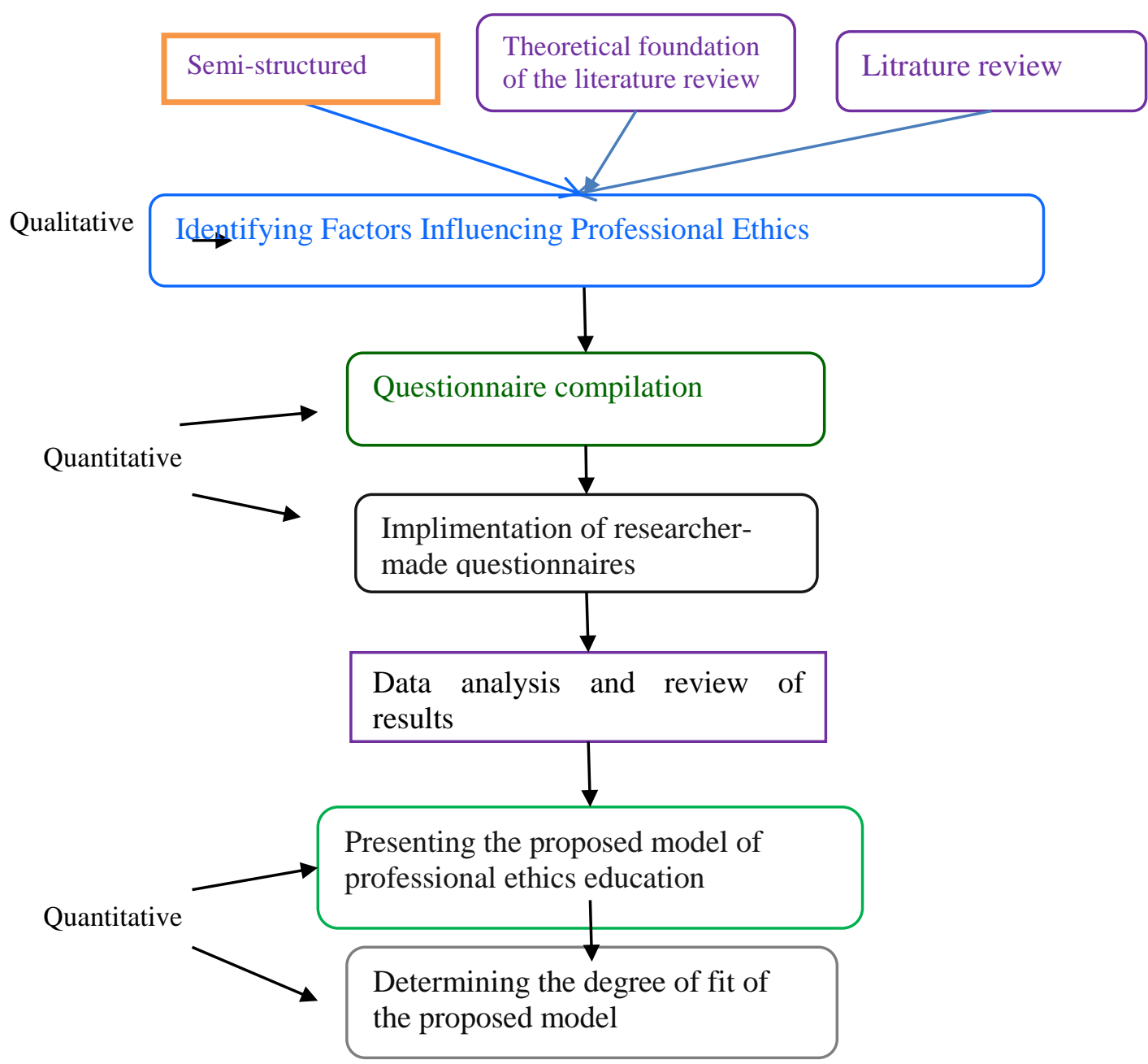

Fig. 1. Steps of the Explanatory Design Research's (20)

\section{Results}

To collect qualitative data, 23 experts of the academic community who had operational experiences at the decision-making level were interviewed. According to demographic information, out of the interviewees, 8 interviewees $(34.78 \%)$ were female, and 15 interviewees (65.22) were male. In addition, in terms of education, 2 interviewees (8.69\%) had baccalaureate degrees, 5 interviewees $(21.73 \%)$ had master's degrees, and 16 interviewees $(69.56 \%)$ had PhDs. In terms of age, 2 interviewees (8.69\%) aged under 40, 8 interviewees (34.78\%) aged 40-45, 7 interviewees (30.43\%) aged $46-50$, and 6 interviewees (26.08\%) aged more than 50 .

Question 1: What are the factors influencing occupational ethics in faculty members at Farhangian University? 
Table 1. Final coding using the semi-structured interview technique

\begin{tabular}{|c|c|c|c|c|c|}
\hline Structure & Dimension & Primarily extracted concepts & $\begin{array}{l}\text { Number of } \\
\text { items }\end{array}$ & $\begin{array}{l}\text { Item } \\
\text { sequenc } \\
\text { e }\end{array}$ & Code \\
\hline \multirow{35}{*}{ 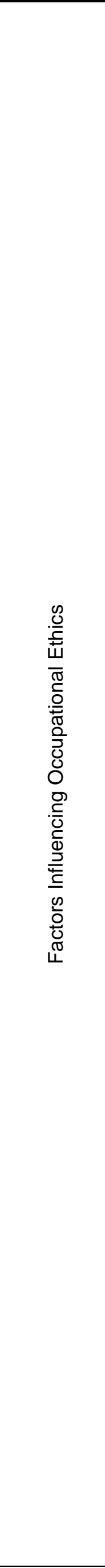 } & \multirow{8}{*}{$\begin{array}{c}\text { Moral } \\
\text { intelligence }\end{array}$} & $\begin{array}{l}\text { This faculty is sincere in its expression and conduct, } \\
\text { and prioritizes honesty in its behavior. }\end{array}$ & \multirow{8}{*}{8} & \multirow{8}{*}{$1-8$} & A1 \\
\hline & & $\begin{array}{l}\text { The professors behave based on their own principles } \\
\text { and beliefs. }\end{array}$ & & & $\mathrm{A} 2$ \\
\hline & & The university professors are trustworthy. & & & A3 \\
\hline & & The university professors forgive mistakes of others. & & & A4 \\
\hline & & The professors have a sense of responsibility. & & & A5 \\
\hline & & The professors admit their mistakes easily. & & & A6 \\
\hline & & $\begin{array}{c}\text { The professors insist on their ethical commitment, } \\
\text { even if it hurts them. }\end{array}$ & & & A7 \\
\hline & & $\begin{array}{c}\text { The professors are always looking for the creation of } \\
\text { an interest in others. }\end{array}$ & & & A8 \\
\hline & \multirow{7}{*}{$\begin{array}{l}\text { Ethical } \\
\text { leadership }\end{array}$} & $\begin{array}{l}\text { At this university, there is an alignment between the } \\
\text { personal and organizational values of the professors. }\end{array}$ & \multirow{7}{*}{7} & \multirow{7}{*}{$9-15$} & B1 \\
\hline & & $\begin{array}{l}\text { The professors of this university are dynamic and } \\
\text { active in implementation of their accepted values. }\end{array}$ & & & B2 \\
\hline & & $\begin{array}{l}\text { The professors trust other members of the university } \\
\text { and convey a sense of trust to others. }\end{array}$ & & & B3 \\
\hline & & $\begin{array}{c}\text { Professors recognize communication as the source } \\
\text { of trust between members. }\end{array}$ & & & B4 \\
\hline & & $\begin{array}{c}\text { The professors have intellectual and practical self- } \\
\text { restraint ability. }\end{array}$ & & & B5 \\
\hline & & $\begin{array}{l}\text { The professors use others' feedback to improve their } \\
\text { characteristics. }\end{array}$ & & & B6 \\
\hline & & $\begin{array}{c}\text { The professors of this university give importance to } \\
\text { the transfer of trainings. }\end{array}$ & & & B7 \\
\hline & \multirow{6}{*}{$\begin{array}{c}\text { Commitme } \\
\mathrm{nt}\end{array}$} & $\begin{array}{c}\text { In this university, professors are given many } \\
\text { responsibilities. }\end{array}$ & \multirow{6}{*}{6} & \multirow{6}{*}{$16-21$} & C1 \\
\hline & & $\begin{array}{l}\text { There is enough trust between professors at this } \\
\text { university. }\end{array}$ & & & $\mathrm{C} 2$ \\
\hline & & $\begin{array}{l}\text { Professors handle social and individual } \\
\text { responsibilities well. }\end{array}$ & & & C3 \\
\hline & & Professors prioritize self-regulation. & & & $\mathrm{C} 4$ \\
\hline & & $\begin{array}{l}\text { Professors hold themselves fully responsible for their } \\
\text { work and even their university. }\end{array}$ & & & C5 \\
\hline & & $\begin{array}{c}\text { The professors of this university try to adapt the } \\
\text { individual perspective of employees to the } \\
\text { organizational perspective. }\end{array}$ & & & C6 \\
\hline & \multirow{10}{*}{$\begin{array}{l}\text { Organizatio } \\
\text { nal culture }\end{array}$} & $\begin{array}{l}\text { At this university, professors follow guidelines } \\
\text { essential to the survival of the organization. }\end{array}$ & \multirow{10}{*}{10} & \multirow{10}{*}{$22-31$} & D1 \\
\hline & & $\begin{array}{l}\text { This university takes clear decisions that give } \\
\text { direction and meaning to our work. }\end{array}$ & & & D2 \\
\hline & & $\begin{array}{c}\text { At this university, all professors believe they can } \\
\text { have a positive impact on works. }\end{array}$ & & & D3 \\
\hline & & $\begin{array}{l}\text { This university has a code of ethics that guides our } \\
\text { behavior and speech in identifying right and wrong. }\end{array}$ & & & D4 \\
\hline & & $\begin{array}{l}\text { This university constantly adopts new and improved } \\
\text { ways of doing things. }\end{array}$ & & & D5 \\
\hline & & This university has a clear strategy for the future. & & & D6 \\
\hline & & Working at this university is like joining a team. & & & D7 \\
\hline & & $\begin{array}{l}\text { When a conflict occurs, the professors seek a } \\
\text { solution for both sides of the conflict to win. }\end{array}$ & & & D8 \\
\hline & & $\begin{array}{c}\text { Suggestions and comments often lead to changes in } \\
\text { the university. }\end{array}$ & & & D9 \\
\hline & & $\begin{array}{c}\text { There is a full agreement between the professors } \\
\text { about the goals of this university. }\end{array}$ & & & D10 \\
\hline & \multirow{4}{*}{$\begin{array}{l}\text { Organizatio } \\
\text { nal climate }\end{array}$} & In this university, everyone respects each other. & \multirow{4}{*}{7} & \multirow{4}{*}{$32-38$} & E1 \\
\hline & & The professor's work together to solve problems. & & & E2 \\
\hline & & $\begin{array}{c}\text { Solidarity is clearly visible on campus and among the } \\
\text { professors. }\end{array}$ & & & E3 \\
\hline & & $\begin{array}{c}\text { The professors at this university appreciate informal } \\
\text { learning. }\end{array}$ & & & E4 \\
\hline
\end{tabular}




\begin{tabular}{|c|c|c|c|c|}
\hline & $\begin{array}{c}\text { The professors adhere to the organizationally } \\
\text { accepted ethics. }\end{array}$ & & & E5 \\
\hline & $\begin{array}{l}\text { The professors in this organization feel they are in } \\
\text { mental health. }\end{array}$ & & & E6 \\
\hline & The professors appreciate each other. & & & E7 \\
\hline \multirow{10}{*}{$\begin{array}{c}\text { Work } \\
\text { engagemen } \\
t\end{array}$} & $\begin{array}{l}\text { The professors at this university are interested in } \\
\text { their work. }\end{array}$ & \multirow{10}{*}{10} & \multirow{10}{*}{$39-48$} & $\mathrm{~F} 1$ \\
\hline & $\begin{array}{l}\text { The university professors feel proud of being in this } \\
\text { place. }\end{array}$ & & & $\mathrm{F} 2$ \\
\hline & The professors are overwhelmed by work. & & & F3 \\
\hline & $\begin{array}{c}\text { This university is very interested in the goals and } \\
\text { values of the professors. }\end{array}$ & & & F4 \\
\hline & $\begin{array}{l}\text { This university gives special importance to the } \\
\text { welfare of the professors. }\end{array}$ & & & F5 \\
\hline & $\begin{array}{c}\text { The achievements of the professors at this university } \\
\text { are honored. }\end{array}$ & & & F6 \\
\hline & $\begin{array}{l}\text { This university abuses the professors unfairly at any } \\
\text { time. }\end{array}$ & & & F7 \\
\hline & $\begin{array}{c}\text { This university would choose some people with lower } \\
\text { salaries if it was possible. }\end{array}$ & & & F8 \\
\hline & $\begin{array}{l}\text { Th university personnel are more interested in } \\
\text { delivering services to others than others serving } \\
\text { them. }\end{array}$ & & & F9 \\
\hline & $\begin{array}{c}\text { The executives in this university encourage others } \\
\text { through behaving as a role model. }\end{array}$ & & & $\mathrm{F} 10$ \\
\hline \multirow{7}{*}{$\begin{array}{l}\text { Interactive } \\
\text { justice }\end{array}$} & $\begin{array}{l}\text { At this university, the administrators treat professors } \\
\text { with justice. }\end{array}$ & \multirow{7}{*}{7} & \multirow{7}{*}{$49-55$} & G1 \\
\hline & $\begin{array}{l}\text { There are healthy relationships between the } \\
\text { professors and the administrators at this university. }\end{array}$ & & & G2 \\
\hline & $\begin{array}{c}\text { The professors at this university have relative peace } \\
\text { caused by healthy communication. }\end{array}$ & & & G3 \\
\hline & $\begin{array}{l}\text { Decisions at this university are made on the basis of } \\
\text { collective wisdom. }\end{array}$ & & & G4 \\
\hline & $\begin{array}{l}\text { There is a balance between the time and volume of } \\
\text { responsibilities assigned in this organization. }\end{array}$ & & & G5 \\
\hline & $\begin{array}{c}\text { Collaboration between the professors and the staff is } \\
\text { a priority at this university. }\end{array}$ & & & G6 \\
\hline & Teamwork at this university is clearly visible. & & & G7 \\
\hline \multirow{7}{*}{$\begin{array}{c}\text { Occupation } \\
\text { al } \\
\text { competenc } \\
\mathrm{e}\end{array}$} & $\begin{array}{c}\text { The professors at this university have sufficient } \\
\text { scientific competence. }\end{array}$ & \multirow{7}{*}{7} & \multirow{7}{*}{$56-62$} & $\mathrm{H} 1$ \\
\hline & $\begin{array}{c}\text { The professors at this university have good } \\
\text { knowledge and attitude. }\end{array}$ & & & $\mathrm{H} 2$ \\
\hline & $\begin{array}{l}\text { The professors at this university are fully acquainted } \\
\text { with modern technologies and technical equipment. }\end{array}$ & & & H3 \\
\hline & $\begin{array}{l}\text { The professors at this university know themselves } \\
\text { well and regard self-awareness as the source of } \\
\text { effective work. }\end{array}$ & & & $\mathrm{H} 4$ \\
\hline & $\begin{array}{c}\text { The employees are constantly learning to gain a } \\
\text { competitive edge. }\end{array}$ & & & $\mathrm{H} 5$ \\
\hline & $\begin{array}{c}\text { The professors have learned classroom management } \\
\text { skills effectively and apply them. }\end{array}$ & & & $\mathrm{H} 6$ \\
\hline & The professors have the ability to motivate others. & & & $\mathrm{H} 7$ \\
\hline \multirow{7}{*}{$\begin{array}{c}\text { Individual } \\
\text { developme } \\
\text { nt }\end{array}$} & $\begin{array}{l}\text { The professors possess the skills of self- } \\
\text { actualization. }\end{array}$ & \multirow{7}{*}{7} & \multirow{7}{*}{$63-69$} & 11 \\
\hline & $\begin{array}{c}\text { The professors are aware of the principles of time } \\
\text { management and apply them. }\end{array}$ & & & 12 \\
\hline & $\begin{array}{l}\text { The professors have acquired the skills of the } \\
\text { accurate use of resources. }\end{array}$ & & & 13 \\
\hline & $\begin{array}{c}\text { The professors consider learning as a factor of } \\
\text { growth. }\end{array}$ & & & 14 \\
\hline & $\begin{array}{c}\text { The professors believe in the empowerment } \\
\text { mechanism as a way to make progress. }\end{array}$ & & & 15 \\
\hline & $\begin{array}{c}\text { The professors recognize their individual needs and } \\
\text { strive to meet them. }\end{array}$ & & & 16 \\
\hline & $\begin{array}{l}\text { The professors care about their physical and mental } \\
\text { health. }\end{array}$ & & & 17 \\
\hline
\end{tabular}

Based on the results of a semi-structured interview

with the experts of the academic community, 
factors influencing occupational ethics were University, with the results presented as follow: identified in the faculty members of Farhangian

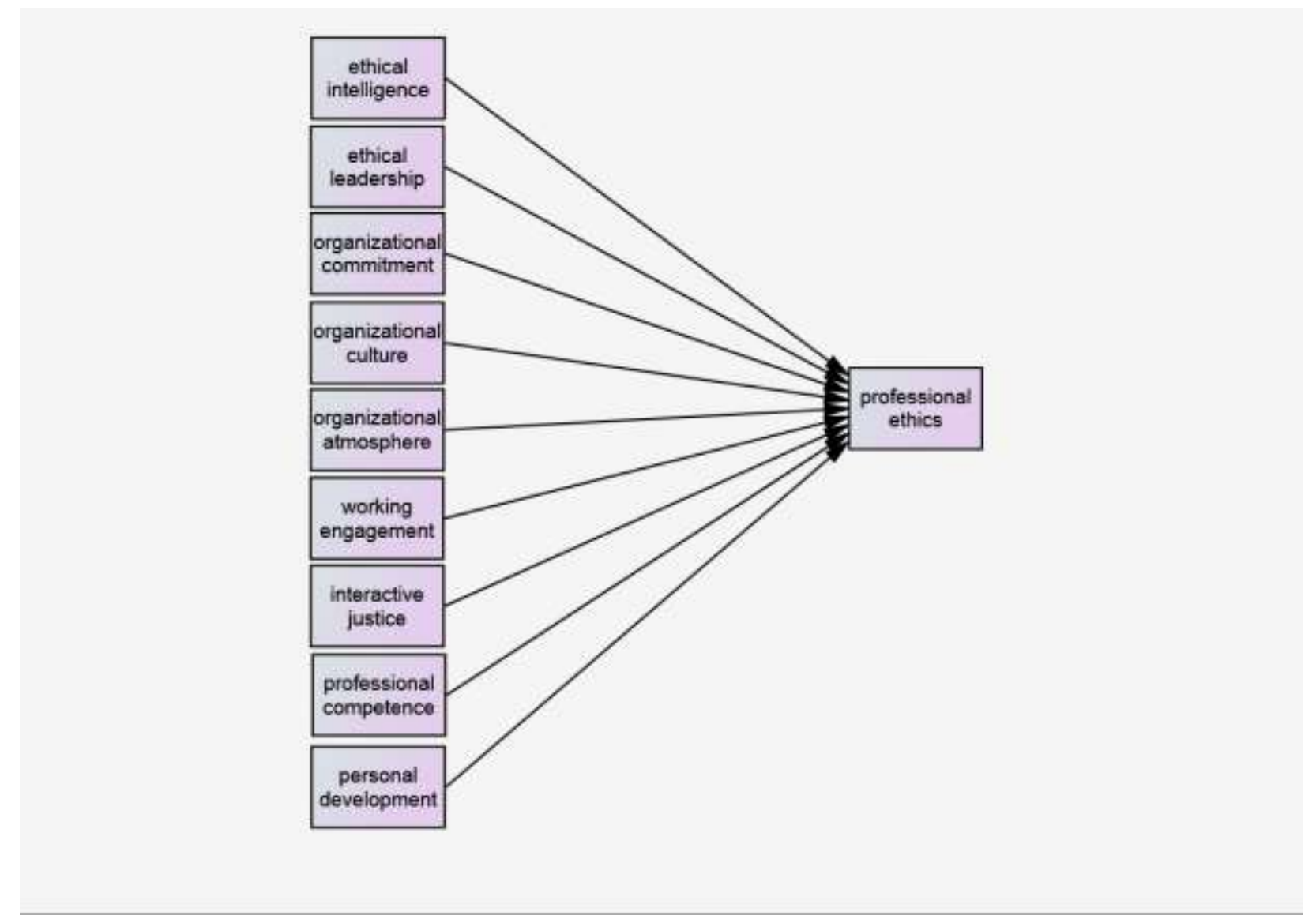

Fig. 2. The model for identified influencing factors taken from the qualitative section

Question 2: What is the status of each identified component in relation to occupational ethics among faculty members at Farhangian University? Path analysis was performed to identify the relationship between each factor and occupational ethics. According to the results, moral intelligence indirectly influenced occupational ethics through organizational commitment and ethical leadership, in addition to its direct impact. In addition, the factor of ethical leadership, in addition to its direct effect, indirectly influenced occupational ethics through the organizational climate. Besides, the factor of organizational culture, in addition to its direct effect, indirectly influenced occupational ethics through ethical leadership and moral intelligence. The other factor, i.e. personal development, in addition to its direct effect, indirectly influenced occupational ethics through the mediating effect of interactive justice. The findings also showed that the factor of organizational climate, in addition to its direct effect, indirectly influenced occupational ethics through work engagement. Likewise, the factor of work engagement, in addition to its direct effect, indirectly influenced occupational ethics through occupational competence.

In the end, according to the results of the present study, the final model of the research was produced as follows: 


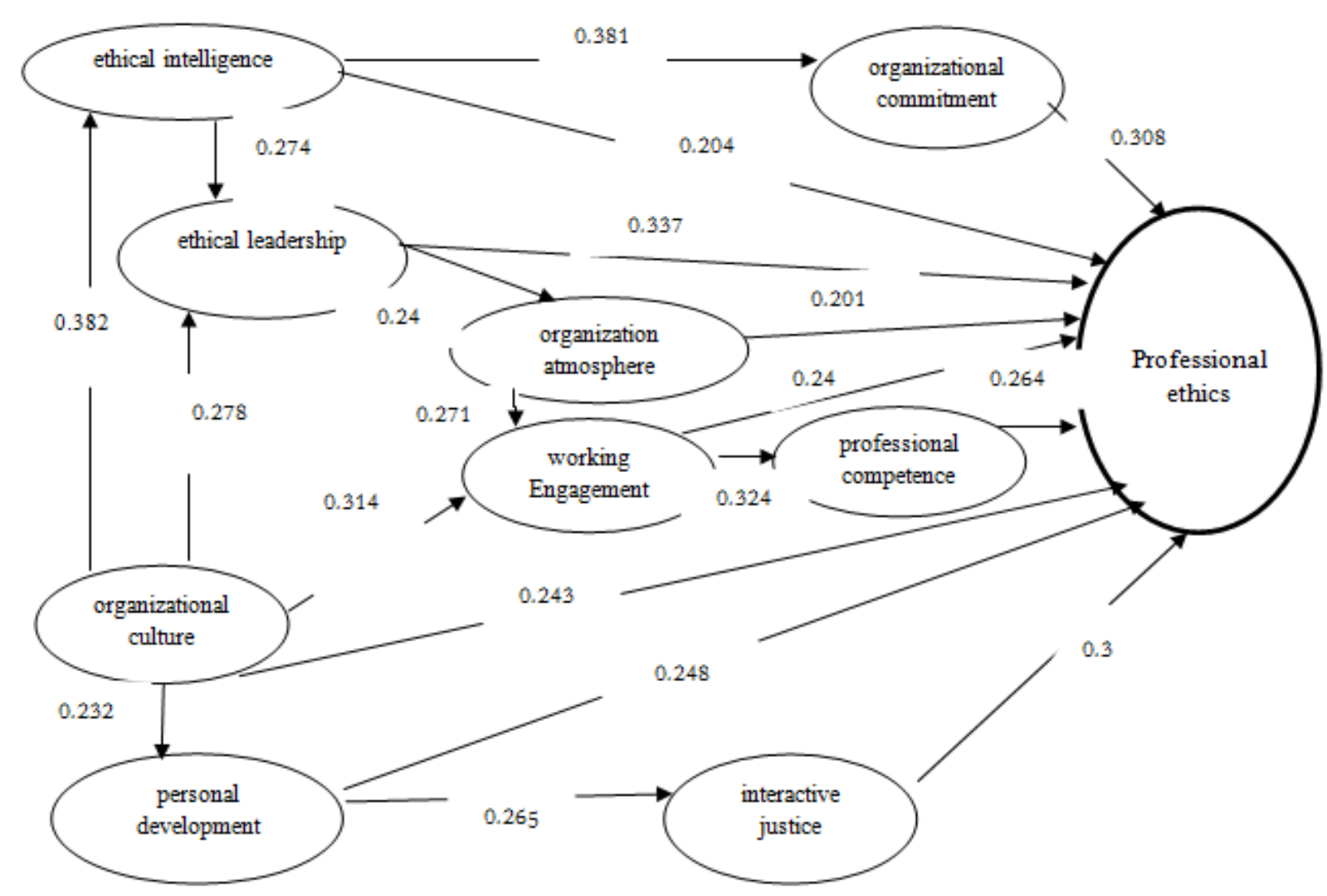

Fig. 3. Final research model

Regression analysis was performed to determine the impact of the identified components on professional ethics. According to the results, the influencing factors of ethical intelligence $(\beta=0 / 204$ $\& p>0 / 00)$, ethical leadership $(\beta=0 / 337 \& p>0 / 00)$, organizational culture $(\beta=0 / 243 \& p>0 / 00)$, personal development $(\beta=0 / 248 \& p>0 / 00)$, organization climate $(\beta=0 / 201 \& p>0 / 00)$, working engagement $(\beta=0 / 240 \& p>0 / 00)$, professional competence $(\beta=0 / 264 \& p>0 / 00)$, and interactive justice $(\beta=0 / 300 \& p>0 / 00)$ had a direction relationship with professional ethics. Also, the results of the path analysis showed that sum of the direct and indirect effects of ethical intelligence, working engagement, organization cultural and personal development on professional ethics are $(\beta=0 / 406), \quad(\beta=0 / 283), \quad(\beta=0 / 607)$ and $(\beta=0 / 327)$ respectively.

What is the status of the model fit?

The following diagram shows that the path fits the data. As the Chi-square and RMSEA indices show, the modified model fits the data better. The model outputs are discussed in Table 2.

Table 2. Path Analysis Fit Indices of the model

\begin{tabular}{ccccc}
\hline Index & Index name & Abbreviation & Value & Acceptable fit(21) \\
\hline \multirow{2}{*}{ Absolute fit indices } & Chi-square/df & - & 2.44 & $3-1$ \\
\cline { 2 - 5 } & Goodness of the fit index & GFI & 0.95 & Higher than 0.9 \\
\hline \multirow{2}{*}{ Comparative fit indices } & Adjusted goodness of the fit index & AGFI & 0.93 & Higher than 0.9 \\
\cline { 2 - 5 } & The comparative fit index & CFI & 0.98 & Higher than 0.9 \\
\hline
\end{tabular}

As the table shows, the fit indices of the model are in a favorable condition.

To investigate content validity, CVR and CVI forms were used. It is worth noting that content validity was assessed by experts, including the interviewees, supervising and advising professors, PhD students in this field, and several subjects before the distribution of the questionnaires. Based on content validity $(C V R=0 / 65$ and $C V I=0 / 84)$, no questions were omitted, but some questions were corrected. After confirming the content and construct validity of the research instrument, two types of convergent and divergent validity was used with the help of Lisrel software. Divergent validity was used by the Fornell and Larker test as well as the transverse load test, and the results of which showed that component reliability was confirmed because the Cronbach's alpha and the composite reliability coefficient were above 0.7 , and AVE was> 0.5. Convergent validity was 
confirmed because of $\mathrm{CR}>0.7 \%, \mathrm{CR}>\mathrm{AVE}$, and AVE> 0.5. In addition, divergent validity was confirmed because of MSV <AVE and ASV <AVE.

\section{Discussion}

The purpose of this study was to design and explain a model for occupational ethics in faculty members at Farhangian University. Based on the obtained results, the variables of ethical intelligence, ethical leadership, organizational commitment, organizational culture, organizational climate, work engagement, interactional justice, occupational competence, and personal development were identified as influencing factors in relation to occupational ethics. In this regard, some of the findings of past research are in line with the findings of the present study; for instance, Shahbazi and Rahgozar (2017) in their study showed that ethical intelligence has a significant correlation with organizational trust [22]. In another study similar to the present one, the researchers concluded that trust and honesty among individuals of an organization lead to occupational ethics [12]. Niazazari et al (2014) stated that occupational ethics had a significant positive correlation with organizational commitment [2]. Mesbahi and Abbaszadeh (2014) found out that occupational ethics consist of five themes, including individual ethics, managerial factors, organizational factors, job ethics, and extraorganizational factors [23]. Behzadi et al (2015) concluded that ethical leadership, ethical climate, and conscientiousness play a central role in explaining the variable of organizational virtuousness [24]. In another comparative study, Fallahi et al (2019) reported the four major variables of professors' characteristics, professors' capabilities, promotion of respect, and promotion of the university as different aspects affecting professional ethics in professors [25].

Moral intelligence is one of the major factors influencing occupational ethics at the faculty. Moral intelligence is the ability to distinguish right from wrong. Professors possessing this type of intelligence have strong ethical beliefs and the ability to apply them. In addition, they treat each other with respect. These professors adjust their behavior based on the values they believe in. Given that the results of this study indicate the positive effect of moral intelligence, to explain the effect of moral intelligence on occupational ethics, one could say that moral intelligence leads to organizational trust. Individuals in their social relationship with each other avoid skepticism and establish an intimate relationship, which could not be realized without having trust in such a relationship. When the level of trust in the organization is high, employees show confidence in the leadership of the organization practically and show more enthusiasm in performing their duties correctly [22]. Ethical leadership is one of the other factors influencing occupational ethics in professors. Teachers who know the components and principles of ethical leadership communicate well with their colleagues and encourage students to develop ethical and appropriate communication. Behzadi et al (2015) showed that ethical leadership improves organizational climate, and according to other researchers, the ethical climate of an organization enables one to anticipate behaviors, such as respect for others, selfsacrifice, as well as honesty and sacrifice [24].

Another feature of professors with occupational ethics is commitment to university issues. Since organizational commitment is a type of emotional devotion to the organization, many employees who achieve their identity from the organization participate in organizational activities and enjoy membership in the organization [26]. They consider themselves responsible for any issues raised in the university and do not spare any efforts in this respect. However, if they do not have necessary organizational commitment and do not consider themselves an effective part of the organization, they will not be able to perform their duties properly and keep behaving ethically. Researchers believe that one of the factors influencing organizational commitment is occupational competence, which was identified as an influencing factor on occupational ethics in this study. According to researchers, occupational competence contributes to improving occupational performance by enhancing occupational commitment [27].

In addition to organizational commitment, organizational culture is a set of values and beliefs to which the faculty members of Farhangian University adhere and perform their duties to improve it. If organizational culture is formed based on accountability, justice, honesty, and respect for each other, it will lead to occupational ethics. Strong organizational culture influences social capital in teachers and fosters ethics. In addition, social capital increases employee willingness to go beyond the requirements of their formal job, thereby directing personal interests in line with organizational objectives and generating a strong interest in the overall activities and philosophy of the organization. Thus, organizational social capital helps foster organizational citizenship behavior within organizations [28]. In addition, researchers believe that educational organizations develop occupationally and ethically when their 
members are developed. Therefore, teachers and professors are considered the major cause of change in the educational system due to their awesome responsibility for educating different people [29]. As a result, based on the findings of this study as well as the existing research literature on the importance of ethics in all aspects of the social life, conducting more research seems to be essential for the identification of factors influencing ethics among teachers and professors. Further research is recommended to be conducted in this field to examine the methods and trainings needed for the reinforcement and improvement of occupational ethics among professors and teachers at Farhangian University. As a result, upon boosting occupational ethics in teachers and professors at Farhangian University, we will be able to foster ethical students and an ethical community.

Although useful findings were achieved in the present study, some limitations existed in the process of conducting this study, similar to other studies. One of the major limitations was the selection of the research sample from faculty members at Farhangian University, which led to difficulties in the generalization of the research results to other university professors and teachers. To overcome this issue, it is suggested that further research be conducted on the current subject with the professors of other universities and teachers included. Therefore, based on the findings of this study, it is concluded that the providing of necessary trainings to enhance ethical competence among faculty members at Farhangian University is required. This is due to the fact that ethical competence positively influences all activities of professors and leads to eagerness and passion among students at Farhangian University towards their professors and what they teach. The results of this research will contribute to the development of ethics throughout the community by following their professors as role models.

\section{Conclusion}

This study was done aimed at identifying factors influencing professional ethics in faculty members at Farhangian University. The results showed that professional ethics in university faculty members could be influenced by different components. Therefore, paying more attention to the importance of ethical components in faculty members at Farhangian University is a must. In addition, the impact of educational and interventional methods for the enhancement of occupational ethics is required to be studied in faculty members at Farhangian University.

\section{Acknowledgement}

The authors would like to express their sincere gratitude to all people who participated in this study.

\section{Conflict of interest: None declared.}

\section{References}

1. Shafipour SF, Zarezeydi A, Metani M. The role of managers' Occupational ethics in Organizations Success. Journal of Applied Studies in Management and Development Sciences 2017; 2(5):38-49.

2. Niazazari K, Enayati T, Behnamfar R, Kahroodi Z. Relationship between Occupational Ethics and Job Commitment. Iran Journal of Nursing 2014; 27(87):34-42.

3. Norouzi R, Dargahi Sh, Aeyadi N, Sarhaddi M. The association between workplace spirituality and Job Stress with occupational ethics through mediating role of Job Enthusiasm among nurses in Zahedan City, 2017. Journal of Occupational Health and Epidemiology 2018; 7(1):3-10.

4. Erfan A, Nadi MA, Ebrahimzadeh R. Analyzing Ethical Factors of Knowledge Commercialization in Higher Education. The journal of Ethics in Science and Technology 2018; 13 (1):108-16.

5. Rezaei A. Study on the Relationship between Organizational Professional Ethics and the Productivity of Human Resources in Khouzestan Ports and Maritime DirectorateGeneral. Journal of Maritime Transport Industry 2017; 3(2): 61-65.

6. Hamidizadeh MR, Nekooeezade M. Occupational Ethics and its Consequences for after Sales Services' Staff in Automotive Industry. Modiriat-E-Farda 2010; 8(22): 3-14.

7. Kolk $A$. The social responsibility of international business: From ethics and the environment to CSR and sustainable development. Journal of World Business 2016; 51(1):23-34.

8. Elias R. The relationship between the protestant work ethic, empathy and business students' distrust of corporations. Southern Journal of Business and Ethics 2016; 8:109-21.

9. Sehhat S, Ehsanfar G, Aslebagh S. The role of ethics in the fraud reduction of insurance companies from customer's point of view (case study: Policy holders of auto insurance department). The Journal of Ethics in Science and Technology 2012; 7(1):55-64.

10. Eweje G, Brunton M. Ethical perceptions of business students in a New Zealand university: do gender, age and work experience matter? Business Ethics: A European Review 2010; 19(1):95-111. 
11. Phalen RF. Core Ethics for Health Professionals. 1st ed. New York City, United States: Springer, Cham; 2017. Professional Ethics, p.75-86.

12. Avatefi Monfared E, Mehdad A, Mirjafari SA. The relationship between ethical leadership, psychological healthy workplace and organizational trust. The Journal of Ethics in Science and Technology 2012; 7(3):44-52.

13. Dehghani A, Eslamiakbar R, Rahimi E, Abbasi Jahromi A, Khaki S. Evaluation of the facilitating factors of professional ethics compliance in nursing practice. Journal of Clinical Nursing and Midwifery 2017; 6(1):19-29.

14. Kelly PT. Integrating leadership topics into accounting ethics course-preparing students for a challenging profession. In: Rupert TJ, Kern BB, editors. Advances in Accounting Education: Teaching and Curriculum Innovations. Bingley, West Yorkshire, England, UK: Emerald Group Publishing; 2017. p.141-80.

15. Banks S. Everyday ethics in professional life: social work as ethics work. Ethics Soc Welf 2016; 10(1):35-52.

16. Miller $\mathrm{Y}$, Kark R, Zohar N. Her/his ethics? Managerial ethics in moral decision-making from a contextual, gendered, and relational perspective. Sex Roles 2019; 80:218-33.

17. Gluchmanová M. Theoretical and practical aspects of a professional ethics of teaching. Hum Affairs 2017; 27(1):75-81.

18. Gall MD, Borg WR, Gall JP. Educational Research: An Introduction. 6th ed. London, England: Longman Publishing; 1996.

19. Azizi Sh, Farhikhteh F. Content, Correspondence and Meta Method Analysis of Marketing Theses in Selected Universities in Tehran. Journal of Business Management (Management Knowledge) 2013; 5(3):105-24.

20. Creswell JW, Clark VLP. Designing and conducting mixed methods research. 3rd ed. Thousand Oaks, California, United States: SAGE Publications; 2017.

21. Hooman HA. Handbook of Qualitative Research. Tehran: Samt Publications; 2015.

22. Shahbazi A, Rahghozar H. The Relationship between Moral Intelligence with Organizational Commitment and Organizational Trust among Employees of Islamic Azad University, Marvdasht Branch. Journal of New Approaches in Educational Administration 2017; 8(2):21943.

23. Mesbahi M, Abbaszadeh A. System model of professional behavior in supreme education (Qualitative research). Bioethics Journal 2014; 3(10):11-34.

24. Behzadi E, Naami A, Beshleideh K. The Relationship between Conscientiousness, Ethical Climate and Ethical Leadership with Organizational Virtuousnes. Journal of Ethics in Science and Technology 2015; 10(1):63-73.

25. Fallahi A, Nemat Shahrbabaki B, Shahoei $R$, Aala F, Ahmadi S. Exploring the Components of Professional Ethics in Teaching, from the Perspective of Faculty Members in Iran. Health Education and Health Promotion 2019; 7(2):95102.

26. Mohammad Davoudi A, Milad M, Shayan Sh. The Relationship between Professional Ethics and Organizational Commitment Mediated by Organizational Justice in Ministry of Health and Medical Education, Deputy of Education. Iranian Journal of Medical Education 2018; 18:541-50.

27. Pourkarimi J, Gharloghi S, Homayni Damirchi A, Karami MR. Mediating Effect of Professional Commitment on the Relationship between Professional Competency and Job Performance (Case Study: The Educationalists in University of Tehran). Journal of Organizational Culture Management 2018; 15(4):833-56.

28. TaghvaieYazdi M, Esmaili H, Fayz Fatemeh M. The Relationship Organiaztional Culture and Organizational Citizenship Behavior with an emphasis on Professional Ethics mediator of employees of Mazandaran Fishery. Journal of Cultural Management 2016; 10(32):1-16.

29. Golaminoghab MH, Pourshafeei H, Shahtalebi Hosseanabadi B. Investigating the Affecting Factors on the Professional Development of Teachers. Quarterly Journal of Educational Leadership \& Administration 2019; 13(2):16781. 